\title{
ECONOMIC ZONES SITE SELECTION IN BUTUAN CITY USING MULTI-CRITERIA DECISION-MAKING APPROACH AND GIS TECHNIQUES
}

\author{
A. G. Cauba Jr. ${ }^{a}$, P. H. C. Coniato ${ }^{a}$ \\ ${ }^{a}$ Department of Geodetic Engineering, College of Engineering and Geosciences, \\ Caraga State University, Ampayon, Butuan City, Philippines - agcauba@carsu.edu.ph
}

KEY WORDS: Economic Zone, Suitability Analysis, Suitability Map, Multi-Criteria Decision-Making Approach (MCDMA), Geographic Information System (GIS), Analytical Hierarchy Process (AHP)

\begin{abstract}
:
Development of economic zones has been rapid in recent years and considered as one of the effective ways of promoting regional growth. Butuan City is categorized as a highly urbanized city and a regional center of Caraga which brings a huge impact to the economic growth in the region. Multi-Criteria Decision-Making Approach (MCDMA) using the pairwise comparison method of the Analytical Hierarchy Process (AHP) and the Geographic Information System techniques were integrated to identify the suitable locations for economic zones. There were nine (9) criteria used in this study such as roads, transport hubs, commercial areas, police station, electric post, water bodies, slope, land use and labor force. Suitability map was produced and used as basis for the analysis. The result of the analysis shows that in Butuan City, an area of $32.15 \mathrm{sq} . \mathrm{km}$ is considered highly suitable, $365.96 \mathrm{sq}$. km is moderately suitable, and $248.43 \mathrm{sq}$. km is low suitable. Most of the areas are considered as moderately suitable for the establishment of economic zones. The information derived from this study would be helpful to the local government of Butuan City and other agencies in determining suitable areas for economic zones. With this information, they may be able to implement solutions in finding the best location for each ecozone which will attract investors and create employment and other opportunities in the city.
\end{abstract}

\section{INTRODUCTION}

Ecozones are looked as distinct areas, wherein firms, usually foreign ones, are supervised outside the normal custom barriers and thus enjoy favored treatment with respect to imports of intermediate goods, taxation, and infrastructure. It has been known to create new employment, generate foreign exchange, expand national revenues, and increase export flows (Senate, 2008). From which, it is considered as an effective method in promoting regional growth (Dace Ziedina, Modrite Pelse, 2017).

This study on land suitability assessment is applying MultiCriteria Decision-Making Approach and Geographic Information System Techniques that enhanced the locator productivity due to the complexity of finding the suitable sites. These techniques have assessed the potential sites in the establishments of Economic Zones in Butuan City. Butuan City as shown in figure 1 is categorized as a highly urbanized city and the regional center of Caraga region which bring a huge impact to the economic growth in the region. It is a strategic trading hub in Northern Mindanao with major roads connecting it to other main cities in the island such as Davao, Cagayan de Oro, Malaybalay, Surigao, and Tandag. It hosts one of the busiest airports in the country, the Bancasi Airport. Meanwhile, the nearby Nasipit International Port and in-city Masao Port are providing for its shipping and cargo needs. Butuan City has a land area of 81,662 hectares, which is roughly $4.1 \%$ of the total area of the Caraga region (CMO, 2016). In 2018, The Gross Regional Domestic Product (GRDP) in Northeastern Mindanao or Caraga region increased to 3.2 percent in 2018. Despite minimal increase in the GRDP in 2018 compared to 2017, officials in Caraga region still noted the continuing progress of the region that could be gleaned from the increase in the number registered businesses in various parts of the region (Sadongdong \& Colina, 2019).

With regard to necessity of Butuan City's ecozones, this study aims to provide valuable information on how to find the best location through mapping and is only limited on mapping the suitable sites for economic zone in Butuan city with respect to its current land use.

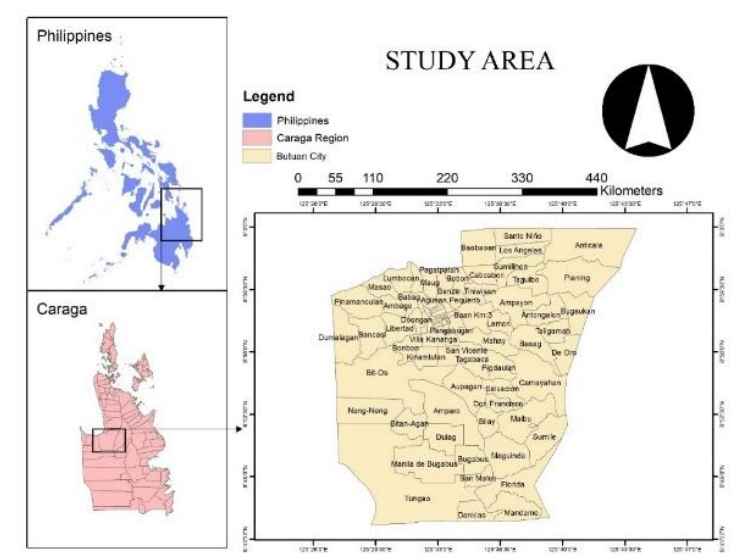

Figure 1. The map of Butuan City

\section{METHODOLOGY}

The methodology consists of the following activities namely: identifying the physical and socio-economic factors for assessing land suitability of economic zones, standardization of data layers of every factor, evaluation of every criterion using Analytical Hierarchy Process (AHP) from the produced data layers and generation of map showing the potential sites for economic zones in Butuan City using Geographic Information System - based analysis.

\subsection{Identification of Physical and Socio-economic Factors} for Assessing Land Suitability of Economic Zones

The Multi-Criteria Decision-Making concept to suitability mapping is to integrate set of criteria to produce a suitability map 
in accordance to its type or specific category and these criteria are associated with its relative weights with the application of AHP. The present study in Special Economic Zone selection, multiple criteria have been considered and used such as locations, linkages, labor force, suitability of industries, incentives and facilitation, and market orientation as important factors for site selection (Waqas Ahmed, 2020). In this study, nine (9) factors were considered to be the basis of the suitability analysis. The factors considered are:

1. Physical factors

$\begin{array}{ll}\text { i. } & \text { Distance to Roads } \\ \text { ii. } & \text { Distance to Transport hubs } \\ \text { iii. } & \text { Distance to Power Sources } \\ \text { iv. } & \text { Distance to Water Sources } \\ \text { v. } & \text { Distance to Police Stations } \\ \text { vi. } & \text { Proximity to Commercial Areas } \\ \text { vii. } & \text { Slope } \\ \text { viii. } & \text { Land Use / Land Cover }\end{array}$

2. Socio-economic factor
i.
Labor Force

\subsection{Standardization of Data Layers}

In standardization, the data was processed and produced through Euclidean distance, conversion of data to raster and reclassification of the data models. All layers were converted into raster data.

The Euclidean distance tool was used to identify the nearest and furthest distance from source. The study used the tool to identify the proximity to the areas from source of different factors such as roads, posts, police station, transport hubs, commercial areas and water bodies. The data were automatically converted to raster data with the same cell size of 100 . Other data such as labor force, LU/LC and slope were converted into raster data.

In reclassification, this tool allows to change many values in an input raster data to get the desired or alternative values for a specific purpose depending on the goal. Reclassification method was applied to each cell within a zone. The analysis is useful when the existing values have to be changed to alternative values. In this study, reclassification was applied since it needs to have the same values as preparation to weighted overlay analysis to generate suitability map.

\subsection{Evaluation of every criterion using Analytical Hierarchy Process (AHP) from the produced data layers}

Weights for the different factors in establishing ecozones were calculated using Analytical Hierarchy Process (AHP) by Thomas L. Saaty. Experts were asked to make a pairwise comparison to each criterion. The rating was the basis in assigning of weights. The table shows the produced weights of the criteria. Land use criterion has the highest weight of $32.6 \%$ which is considered as the most important criteria and followed by water and power sources which are considered also the second most important of the criteria having weights of $20 \%$ and $14.3 \%$, respectively.

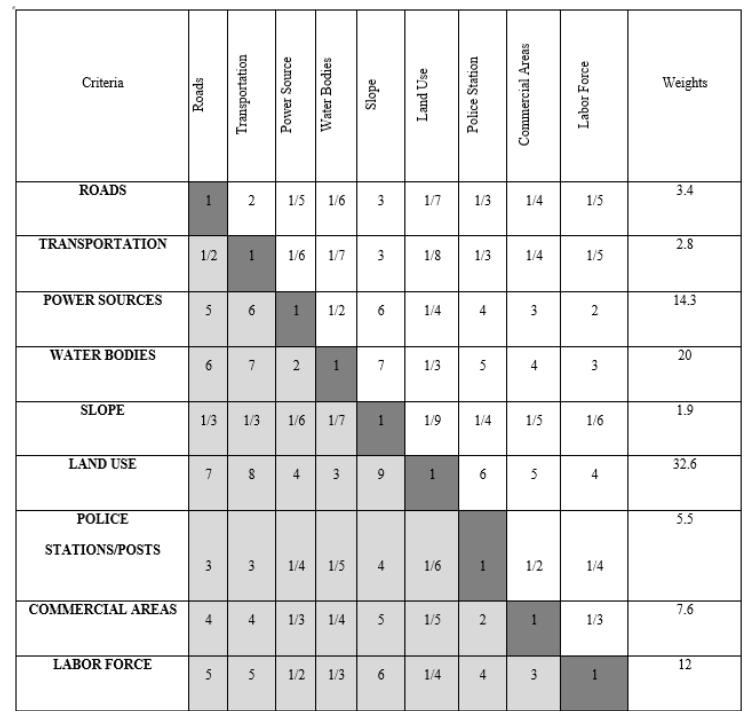

Table 1. The pairwise comparison matrix and the corresponding weights

\subsection{Generation of Suitability Map for Economic Zones}

All the reclassified raster datasets of the criteria were used as inputs along its weight. Datasets were overlaid according to each importance and generate a suitability map. The weighted overly analysis was used to generate the map showing the potential sites for economic zone development in Butuan city.

\section{RESULTS AND DISCUSSION}

\subsection{The Suitability Map}

The generated map as shown in figure 2 presents the suitability map of the potential sites for economic zone in Butuan City. Based on the map, red color represents high suitability. This area occupies the small portion of the city's total area yet occupying most of the urban barangays in which it is the center for income generation and the place where most of the high commercial establishments are located. The map also shows that most part of the area is considered as moderately suitable for ecozone development as shown in light green color. Lastly, the extra light green color represents low suitability.

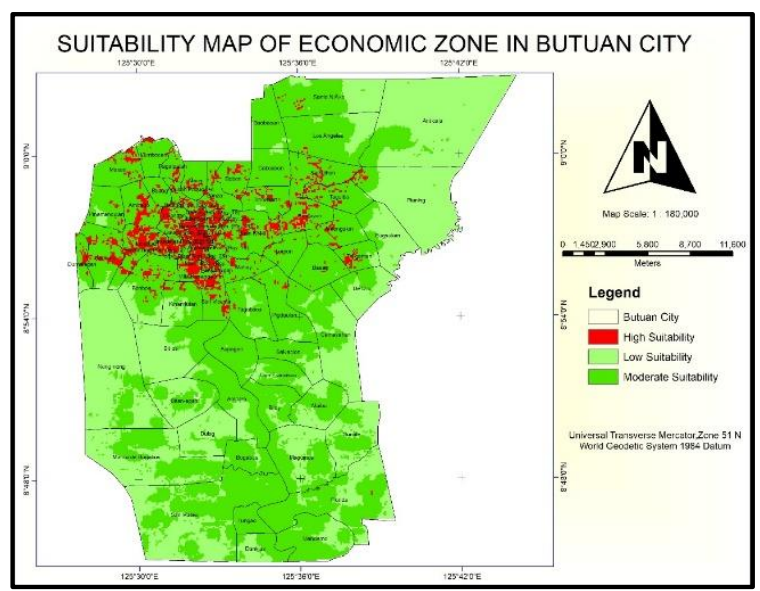

Figure 2. The suitability map for ecozone development in Butuan City 


\subsection{Total Area for Suitable Sites}

Figure 3 shows the classified area as high suitable, moderately suitable and low suitable with its equivalent values of area in sq. $\mathrm{km}$. The moderately suitability areas cover an area of 365.96 sq.km. While the highest suitable areas occupy the smallest area of 32.15 sq.km.

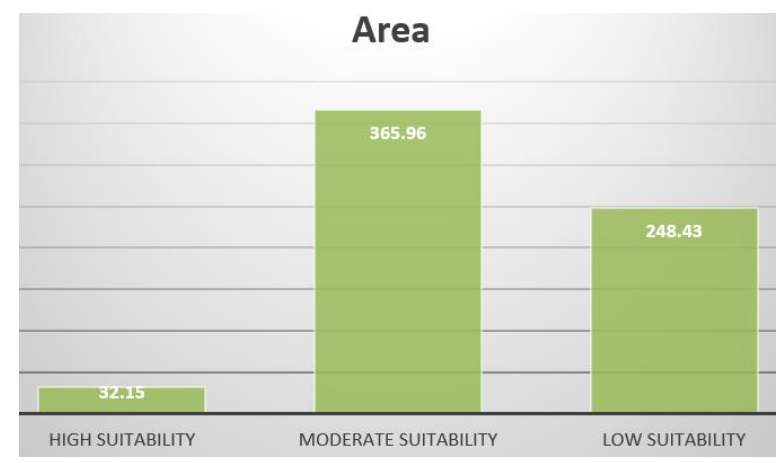

Figure 3. Total area in sq.km

\section{CONCLUSIONS AND RECOMMENDATIONS}

The main objective of the study is to generate suitability map to assess the potential sites for the development of economic zones in Butuan City using Multi-Criteria Decision-Making Approach and Geographic Information System. The use of Analytical Hierarchy Process (AHP) and Geographic Information System (GIS) techniques were found very effective in providing the results for suitability analysis and maps. The results suggest that in finding suitable sites for economic zones, it should focus on the part where most developed areas are situated. Although the map has shown lesser areas of highly suitable sites than others but moderate and low suitable sites can also be considered upon thorough planning. This information can help the planners of the city to provide more scientific method of finding the best locations for the development of economic zones.

Considering that the map can be used for assessing the potential sites for ecozone development, it is still recommended to integrate more possible criteria and parameters for much more detailed analysis and to consider all types of economic zone for a very specific map result. Lastly, having an updated dataset will produce detailed and better results.

\section{ACKNOWLEGDEMENT}

The researchers extend their gratitude to Caraga Center for GeoInformatics (CCGEO), BPMIS, ANECO for providing valuable data for analysis. Lastly, to Almighty God for His abundant love, and infinite blessings.

\section{REFERENCES}

CMO, 2016. Butuan. [Online] Available at: https://www.butuan.gov.ph/cgbgov/page/about$\underline{\text { butuan }}$

[Accessed December 2019].
Dace Ziedina, Modrite Pelse, 2017. Economic Science for Rural Development. Main Characteristic of Economic Zones Types: Latvia's Experience, pp. 212-218.

Sadongdong, M. \& Colina, A., 2019. news.mb.com.ph. [Online] Available at: https://mb.com.ph/2019/07/03/economic-growthcontinuous-in-caraga-region/

[Accessed December 2019].

Senate, 2008. Senate.gov.ph. [Online] Available at: https://www.senate.gov.ph/publications/PB\%202008-06\%20\%20Creation\%20of\%20Ecozones.pdf

[Accessed October 2019].

Waqas Ahmed, Q. T. Y. A. S. a. S. A., 2020. Sustainable and Special Economic Zone Selection under Fuzzy Environment: A Case of Pakistan. Symmetry. 